\title{
The Automation Of Robotic Processes In Jordanian Banks: Obstacles And Applications
}

\author{
Prof. Abedalfattah Zuhair Al-abedallat \\ Department of Banking and Finance, Faculty of Business and Finance, \\ The World Islamic Sciences \& Education University, \\ Jordan P.O., Amman, Jordan \\ Dr. Ali Bakhit Jaafreh \\ Business Department, Shaqra University, KSA \\ Dr. Duraid Kamel Alshbib \\ Dean of Economic and Business Administration \\ American University for Human Sciences, USA
}

Doi:10.19044/esj.2021.v17n21p350

Submitted: 10 June 2021

Accepted: 16 June 2021

Published: 30 June 2021
Copyright 2021 Author(s)

Under Creative Commons BY-NC-ND

4.0 OPEN ACCESS

Cite As:

Zuhair Al-abedallat A., Jaafreh A.B. \& Alshbib D.K. (2021). The Automation Of Robotic Processes In Jordanian Banks: Obstacles And Applications. European Scientific Journal, ESJ, 17(21), 350.

https://doi.org/10.19044/esj.2021.v17n21p350

\section{Abstract}

This paper focuses on identifying the impact of technical and financial obstacles to the applications and expansion of the smart branches of banks in Jordan. This, however, depends on the Automation of Robotic Processes to identify the reality of applying smart branches in the world, including Jordan. The study employed a sample of 100 employees selected in an equal random manner from 25 Jordanian banks. With its spreading strands, multiple linear regression was used to test the hypotheses of the study. The study concluded that the expansion of banks of smart branches (robots) contributes to reducing operational cost and increasing the bank's profits by reducing the cost of banking service, enhancing its quality, increasing the market share of banks, and reducing the technical and financial obstacles that have a significant impact on the expansion of the smart branches of banks. The study recommended the importance of the development of smart branches of banks in Jordan due to its benefits in reducing the costs of the provided banking 
service. This contributes to increasing its profits. Also, banks should hold specialized training courses for bank workers on how to use the new technology. Banks should also allocate funds needed to create the essential infrastructure for the smart branch Applications of Artificial Intelligence, as this has an impact in achieving competitive advantage.

Key Words: Robotic Process Automation (RPA), Artificial Intelligence, Technical Obstacles, Financial Obstacles, Robots. Jordan, Banks

\section{Introduction}

The banking sector is faced with a lot of challenges resulting from innovative technology that are indispensable for banks to achieve sustainable growth or remain in an environment characterized by intense competition. This is because modern technology has huge potential to bring about a change in the way banks conduct their banking business. The digital transformation of banks has become an urgent matter to reduce the movement of customers towards the branches, and the reduction of operating expenses. Consequently, the technology has moved from just the traditional use of the banking sector to drive the strategies that the bank adopts in its banking business (Neill, 2017).

The journey of technological innovation began in the banking services through Internet banking, mobile phones or smartphones, and electronic payment. The adoption of advanced technology and the use of artificial intelligence techniques are the biggest challenges affecting the banking business. This is because these advanced technologies have great potential to provide the best innovative electronic banking solutions to customers, attract more of them, enhance bank profits, and increase customer demand for banking services provided digitally because of the increasing confidence of customers in banks that are moving towards expansion in modern technologies (Castelli, Manzoni \& Popovic, 2016).

Banks can reduce the operational cost to about $50 \%$ by reducing the number of administrative and operational office employees who provide daily services to customers. This can be achieved through their reliance on relatively low-cost and highly efficient technology. Also, banks had adopted chatbot applications to communicate and deal with customers in the same way as a customer service employee. The chatbot is a computer program designed to conduct conversations with humans in a way that simulates chatting between two people, and this leads to shortening of time. According to Brush and Scardina (2019), various applications such as machine learning helps in dealing with fraud and the hacking of banking systems. The Chinese, one of the major financial institutions in China, opened the first bank branch that relies on smiling robots in its entirety instead of employees in Shanghai, 
China. In the business world, the application of Financial Technology (FinTech) will provide the ability to compete because FinTech provides speed and flexibility and are more dynamic than changes in financial services (Meyiana, Fernando \& Surjandy, 2019).

Routine tasks to more complex and interesting tasks that bring great added value, Robotic Process Automation (RPA) (the use of software "robots" to automate repetitive, clerical, and typically high-volume tasks), has become one of the most sought after technologies in the banking sector. Thus, the worldwide RPA software and services market is expected to grow to $35 \%$ reaching $\$ 1.2$ billion by 2021. An RPA tool, triggered manually or automatically, moves or populates data between prescribed locations, document audit trails, conduct calculations, perform actions, and trigger downstream activities without changing the IT structure of the company (IBS Intelligence).

\section{Problem of the Study}

Jordanian banks operate under intense competition and a world where technology is rapidly developing. Banks that are late in developing themselves and keeping pace with changes in technology will not continue in the market. This is because investment in technology is the most important factor for the success of the future of banking continuity, and scientific research confirms the importance of investment in providing banking services based on modern technology.

The problem of the study is the nature of the intense competition locally and abroad facing Jordanian banks, as 25 Jordanian and foreign banks (abj.org.jo) operate in Jordan. Therefore, these banks must adopt the artificial intelligence techniques in banking such as smart branches working through robots without the need for employees. This reduces the operating costs of banks, increases the bank's market share, and contributes to the high rates of bank profits. Nonetheless, banks face many technical and financial obstacles that limit them from adopting the RPA.

Based on the above, this study will answer the following questions that express the problem of the study:

1. Is there an application for smart branches (robots) in Jordanian banks?

2. Are there any advantages for banks provided by smart branch application?

3. What is the impact of the technical and financial constraints on the expansion of banks in the applications of smart branches?

4. What are the key factors that influence the adoption of RPA in the retail banking industry to enhance the customer experience? 


\section{Objectives of the Study}

The objectives of this study are an attempt to identify the following:

- The reality of implementing smart branches in Jordanian banks;

- The effect of implementing smart branches in achieving competitive advantages for Jordanian banks;

-The most important obstacles that prevent banks from expanding the use of smart branch applications.

\section{The Importance of the Study}

-The importance of smart branch applications (robots) in increasing banks' market share;

-The importance of smart branch applications (robots) in reducing costs and increasing profits;

-The impact of technical and financial obstacles on the expansion of banks into smart branches;

-The scarcity of scientific studies in the field of artificial intelligence applications in Jordan.

\section{Hypothesis}

There is no statistically significant effect of Technical and Financial obstacles on the banks' expansion of the smart branch applications in Jordanian banks at a significant level $(\mathrm{a} \leq 0.05)$.

\section{The First Sub-hypothesis, Ho-1}

There is no statistically significant effect of the technical obstacles on the banks' expansion in the applications of smart branches in Jordanian banks at a significance level $(\mathrm{a} \leq 0.05)$.

\section{The Second Sub-hypothesis, Ho-2:}

There is no statistically significant effect of the financial obstacles on the expansion of banks in the applications of smart branches in Jordanian banks at a significance level $(\mathrm{a} \leq 0.05)$.

\section{Study Model}

The study model is based on the study problem, the theoretical framework, and previous studies as illustrated below:

Independent variables

\begin{tabular}{|c|c|}
\hline Obstacles & \multicolumn{1}{|c|}{$\begin{array}{c}\text { Artificial Intelligence } \\
\text { Applications }\end{array}$} \\
\hline Financial obstacles & \\
\hline Technical obstacles & Smart branch \\
\hline
\end{tabular}

Figure 1. The Framework of Study (by Researchers) 


\section{Theoretical Framework and Previous Studies Artificial Intelligence}

The main impulses for starting AI came from the US (Bibel, 2014). The term "artificial intelligence" began in the early sixties when the scientist (Minsky) published a paper entitled "Steps towards Artificial Intelligence". This developed concept refers to a specialized scientific field aimed at computer programming to possess the ability to think, solve problems, make decisions, and distinguish voices, pictures, and understanding texts written in a natural language in a way that simulates human capabilities (AL-Kayat \& Faidi, 1998). Sharma (2011) and Luger (2005) defined Artificial Intelligence as: "It is the science of enabling computers to do things that require intelligence, such as humans, and interaction with a big amount of data to help the decision-maker."

\section{Artificial Intelligence Applications in Banking}

Artificial intelligence and robots will replace the human race in both industries and daily life.

Robots are computerized, which serves as a good replacement for jobs such as office administration, call-center staff, etc. (Dirican, 2015).

Artificial intelligence technologies have brought about pivotal changes in various aspects of banks' practices for their business and the patterns of customer interaction in the banking sector. Since this sector is considered as one of the sectors mostly affected by advanced technology, some of the important applications of artificial intelligence include the following:

\section{First: Chatbot}

A chatbot is a software tool that utilizes natural language processing for human-machine interaction because the banking industry was one of the first industries to adopt the technology (Doherty, Curran, 2019). It is a machine that is specially programmed and controlled by a computer (Nair, 2018).

In another definition, a chatbot is a computer program designed to conduct conversations with humans, in a way that simulates chatting between two people. This smart software uses techniques called natural language processing to understand customers' input (voice or text) regarding their inquiries and the implementation of the required banking services. Thus, it deals with a huge amount of customer inquiries and services, which helps bank employees to focus on important customer issues, innovation, and renewal (Al-Fagi, 2012).

It is software that interacts with human orders, provides services to customers around the clock (seven days a week), and works to reduce costs. The Royal Bank of Scotland uses the Chatbot technology, by which it launched the chat technology called "Luvo" to help the bank carry out daily 
business. In addition, the customer has access to many banking services using a password, such as cash operations, account statement, and identification of bank products without the need to use the bank card (H-Farm Industry - A I Team, 2017).

Among the banks that launched this service in 2016, Mashreq Bank is one of the distinguished banks in the United Arab Emirates. This service called "Mashraq Bot" can be accessed by selecting the "Facebook Messenger" application and then choosing "Mashraq Bot". Here the customer enters the conversation interface with the robot, and then it identifies the customer through a series of steps related to the Internet banking and a password associated with the mobile phone number registered with the account. After authentication of the user's identity, the robot becomes effective for obtaining banking services in an easy way and from anywhere (www.mashreqbank.com).

In the UAE, Abu Dhabi Commercial Bank has established for the first time a digital banking service center called "UBank". This center is a smart new experience that provides banking services to customers faster. Among the most important services provided is the opening of an account immediately and obtaining a new credit card. The advantage of this service is that it helps to protect the environment because banking transaction is completed quickly without any paper work, and the customers can access the service at any time (www.adcb.com).

In Jordan, Jordan's National Bank was the first Jordanian bank to offer a chat service under the name "ahlibot" at the beginning of 2018, as the bank tries to take advantage of the service's feedback to develop it (www.alahlionline.com).

Dash (2018) indicates that the Indian banking industry have developed a new technology for their customer service, which is the use of artificial intelligence in creating chatbots to facilitate the user's access to the banking service, as chat robots began to make their mark in the Indian banking industry. The beginning was with Kotak Bank (Kotak Mahindra Bank) who developed the first program called "Keya". Keya is an intelligent voice program developed based on technology that can understand customer voices and chat to provide a quick response to customer requests. Therefore, this leads to increased customer satisfaction, speed of response, and a significant reduction in costs. Bank of Baroda has also deployed a chatbot to deal with the overwhelming volume of customer inquiries regarding the products.

The State Bank of India is considered to be one of the largest public sector banks in India, with over 420 million customers. The bank has expanded the use of a chatbot called "SIA", where 10,000 inquiries are dealt with per second, i.e., a total of 486 million inquiries. Consequently, the bank installed cameras in its branches through which they scanned customers' facial 
expressions and send reports directly to bank employees (Baraokar \& Anand, 2018).

\section{Second: Smart Branches}

Smart branches are the branches of banks that mainly rely on robots in their work without the employees. The first experience of smart branches was in the Construction Bank, which is one of the largest financial institutions in China with a branch established in Jiujiang Street in Shanghai. In this case, the branch relied entirely on robots to serve customers by implementing human-executed operations such as: talking with customers, receiving complaints, and answering common questions related to bankcards, checks, and accounts. Moreover, as soon as the customer enters the branch, the customer receives the reception manager (robot) who identifies him through the technique of "face scanning". Here, the door opens and the robot interacts with customers through the voice communication system and guides customers to different service areas.

The smart bank does not need employees to participate in transactions, but rather the smart branches use technologies such as biological recognition, voice recognition, data mining, and recognition in the face to provide smart self-service to customers characterized by intelligence and innovation (Neill, 2017).

\section{The Benefits of Using Robots}

Robotic Process Automation (RPA) known as a software Robot or Bot mimics a human worker (Nair, 2018). RPA is a modern and innovative technology that allows companies to increase operational productivity significantly by replacing people with software robots. The benefits of PRA are as follows:

1. Software robots perform tasks faster than humans and are available to perform tasks around the clock without making mistakes.

2. Software robots allow the organization to free and redistribute human resources, reduce operating costs from 50 to $70 \%$, and record every action and allow flexible control of operational productivity.

3. The Software robots interact with existing systems and applications through the interface without changing the IT infrastructure (Kanakova Prokhorovb, 2020).

\section{Obstacles to the Expansion of Banks in the Application of Artificial Intelligence}

AI and RPA together mean that a Big Data turned into actionable insights, but investing in them is very costly (gottgddt et al., 2020). The use of advanced technology is an inherent element of the banking business due to the speed it 
provides in providing banking service and the ability to develop new products. Al-Hawary, Bani-hani and Al-Sakarneh (2011) refer to a set of obstacles facing banks in terms of IT which is related to the expansion of modern technology. Thus, they include:

1. IT Infrastructure Constraints: The infrastructure includes Hardware, Software, Databases, Networks, Communications, and the Internet.

2. Technical Obstacles: It relates to the administrative staff who can deal with new applications. This staff needs to be qualified through specialized training courses to be able to use this new technology.

3. Security Obstacles: These obstacles refer to maintaining the security and confidentiality of information, preventing entry of unauthorized persons to enter the financial system, and preventing piracy. This is because any breach in operations may cause a great financial loss to the bank.

\section{Previous Studies}

Many applied studies have dealt with the subject of artificial intelligence applications for banks. For instance, Saleh (2009) discussed the effect of applying artificial intelligence and emotional intelligence methods on the quality of administrative decision-making in Jordanian commercial banks. The study reached many results and the most important of them is that there is a statistically significant relationship between the use of artificial intelligence and emotional intelligence methods and the quality of taking administrative decisions. Also, there is a statistically significant relationship between the type of smart program used in artificial intelligence and the quality of decision-making. The study recommended developing the skills of bank employees in dealing with artificial and emotional intelligence methods.

Al-Adaileh, Al-Mobaideen and Al-Smairat (2017) studied the factors affecting the use of electronic banking services via the Internet. The problem of the study was the deficiency and weakness of the customers' use of electronic banking services. The study concluded that the factors (level of technical skill, perceived interest, and availability of information) have an impact on the level of use of electronic banking services via the Internet. The study recommended bank departments to pay more attention to the trust factor through brochures, the factor of safety and confidentiality, to increase customer adoption of internet banking services.

Mohamed (2017) focused on identifying the relationship of obstacles between the technical implementation of the quality function (information technology infrastructure, technical obstacles, security obstacles, customerspecific obstacles, and technical obstacles) and the perceived quality of electronic banking services. The study concluded that there is a positive correlation between them, as the correlation coefficient reached $80.7 \%$. The study recommended the necessity for banks to diversify the tools and means 
of marketing electronic banking services, especially through e-mail, providing the infrastructure for information technology, and establishing banks as a specialized center for development.

Castelli, Manzoni and Popovic (2016) discussed building a model based on artificial intelligence to predict the quality of banking service, and the study focuses on the quality issue of the time it takes for the customer to obtain the service, as bank administrations may decide to open new branches to meet customer requests. The study indicates that the introduction of artificial intelligence applications leads to an increase in the quality of banking service, thus increasing customer loyalty, so a balance must be made between providing high-quality banking services by expanding the applications of artificial intelligence and reducing operational costs.

Kumar et al. (2018) aimed to identify the role of artificial intelligence applications in supporting the bank's communication with its customers through banking chat, through which smart solutions can be provided that helps to increase and improve the quality of services provided to customers, thus providing customers with banking services around the clock. The study concluded that the expansion of the use of chat technology through artificial intelligence techniques help in self-learning and in reducing the use of employees.

Al-abedallat (2020) aimed to identify the impact of artificial intelligence applications on achieving a competitive advantage. The study concluded that banks' expansion in artificial intelligence applications achieves the competitive advantage of banks by reducing the banking service cost, enhancing quality, and increasing the market share of banks. The study recommended emphasizing the importance of bank expansion in Jordan using artificial intelligence applications. It has been significant in achieving the competitive advantage of banks, particularly reducing the banking service cost provided, which would maximize its profits (Al-abedallat, 2020).

\section{Methodology}

This study is both descriptive and analytical. It is descriptive through a theoretical literature survey by referring to references, sources, and scientific periodicals to build the theoretical framework of the study. In terms of being analytical, a questionnaire was designed to collect data related to the subject of the study. These data were analyzed statistically to extract results by testing the hypotheses of the study so as to achieve its objectives. The sample of the study comprises of 25 banks operating in Jordan (www.cbj.gov.jo), where 100 employees were selected in a systematic random manner. Researchers used the SPSS software for statistical analysis.

The study tool represented in the questionnaire was prepared for identifying the impact of technical and financial obstacles on the expansion of 
banks into smart branches. The theoretical literature and previous studies were used to determine the study question formulas.

\section{The Validity of the Questionnaire}

To verify the validity of the questionnaire, it was presented to a group of academics and specialists in the banking sector, and they reported the validity of the questionnaire for the study.

\section{First: Testing the Stability of the Study Tool}

The stability of the study tool was confirmed by conducting an internal consistency test and extracting the stability parameter (Cronbach Alpha) on the study sample. Here, the alpha value of all variables of the study and the result, in general, exceeded the required minimum (60\%), which is an acceptable percentage in scientific studies (Zikmund et al., 2009). Table 1 illustrates this.

Table 1. The values of $\alpha$ for the study variables

\begin{tabular}{|l|l|}
\hline$\alpha$ Value & \multicolumn{1}{|c|}{ Variables } \\
\hline 0.85 & $\begin{array}{l}\text { Independent Variable: Technical and Financial constraints to } \\
\text { expansion }\end{array}$ \\
\hline 0.81 & Dependent Variable: Smart Branches (Robots) \\
\hline
\end{tabular}

To ensure the suitability of the study data, the researchers applied the regression analysis. Also, a normal distribution test was performed to ensure that the data were normally distributed. A skewness test was performed and it was found that the values of the Torsion Coefficient of the independent variables are less than one, and the significance of the Kolmogorov-Simonov test was greater than 0.05 .

Among the independent variables using the Variance Inflation Factory test and the Tolerance test, the criterion is that the VIF does not exceed the value of 10. and the value of the permissible variance test is greater than 0.05 (Sekaran \& Bougie, 2009). By conducting the test on the independent variables, the results can be seen in Table 2 below:

Table 2. Model suitability test for regression test

\begin{tabular}{|l|l|l|l|l|l|}
\hline \multicolumn{1}{|c|}{$\begin{array}{c}\text { Tolerable } \\
\text { variance }\end{array}$} & $\begin{array}{c}\text { Contrast } \\
\text { amplification } \\
\text { factor }\end{array}$ & Sig. & K-S & Skewness & Study variables \\
\hline 0.324 & 2.651 & 0.461 & 00.771 & 0.036 & $\begin{array}{l}\text { Financial } \\
\text { obstacles }\end{array}$ \\
\hline 0.341 & 2.456 & 0.332 & 0.756 & 0.78 & $\begin{array}{l}\text { Technical } \\
\text { obstacles }\end{array}$ \\
\cline { 3 - 6 } & & 0.431 & 0.884 & 0.21 & Smart branches \\
\cline { 2 - 6 }
\end{tabular}




\section{Second: Presenting the Results of the Study}

Based on the analysis of the demographic characteristics of the study sample, Table 3 below shows the demographic variables:

Table 3. The demographic variables for the study sample

\begin{tabular}{|c|c|c|c|}
\hline$\%$ & No. & Property & Variable \\
\hline $65 \%$ & 65 & Male & \multirow[t]{3}{*}{ Gender } \\
\hline $35 \%$ & 35 & Female & \\
\hline $100 \%$ & 100 & Total & \\
\hline & & Less than 25 & \multirow[t]{6}{*}{ Age } \\
\hline $22 \%$ & 22 & From $25-30$ & \\
\hline $35 \%$ & 35 & From 31-40 & \\
\hline $33 \%$ & 33 & From 41-50 & \\
\hline $10 \%$ & $10 \%$ & From 51 and over & \\
\hline $100 \%$ & 100 & Total & \\
\hline $5 \%$ & 5 & Diploma and below & \multirow{5}{*}{$\begin{array}{c}\text { Educational } \\
\text { attainment }\end{array}$} \\
\hline $20 \%$ & 20 & Bas & \\
\hline $70 \%$ & 70 & M.A. & \\
\hline $5 \%$ & 5 & PHD & \\
\hline $100 \%$ & 100 & Total & \\
\hline- & _ & From 1-5 & \multirow{6}{*}{$\begin{array}{c}\text { Practical } \\
\text { experience }\end{array}$} \\
\hline $30 \%$ & 30 & From6-10 & \\
\hline $50 \%$ & 50 & From 11-15 & \\
\hline $10 \%$ & 10 & From $16-20$ & \\
\hline $10 \%$ & 10 & From 21 and above & \\
\hline $100 \%$ & 100 & Total & \\
\hline $5 \%$ & 5 & $\begin{array}{c}\text { General Manager / Deputy General } \\
\text { Manager }\end{array}$ & \multirow[t]{4}{*}{ Career site } \\
\hline $80 \%$ & 80 & Assistant General Manager / Director & \\
\hline $15 \%$ & 15 & Assistant Manager / Head of Department & \\
\hline $100 \%$ & 100 & TOTAL & \\
\hline
\end{tabular}

\section{Third: The Answers of the Study Sample}

The answers of the study sample individuals for each of the independent and dependent variables show a high degree of importance. Thus, this is evident from Table 4 below.

Table 4. The arithmetic means and standard deviations of the items that measure the study variables

\begin{tabular}{|c|c|c|c|}
\hline Deviation Standard & Arithmetic mean & Variables & The sequence \\
\hline 0.70 & 3.81 & Technical constraints & 1 \\
\hline 0.86 & 3.74 & Financial constraints & 2 \\
\hline 0.91 & 3.80 & Smart Branches & 3 \\
\hline
\end{tabular}


Therefore, the researchers note the following:

-The technical constraints achieved a total arithmetic average of 3.81, which is of a high level; this indicates the banks 'awareness of the role of technical obstacles in limiting the expansion of banks into smart branches.

-The financial constraints achieved a total arithmetic average of 3.74, which is on the high level; this indicates the banks' awareness of the role of financial obstacles in limiting the expansion of banks into smart branches.

-As for smart branches, it achieved a total average of 3.80, which is a high level; this indicates the interest of banks and their awareness of the importance of smart branches in enhancing the competitive advantage of the bank, especially reducing costs and enhancing the quality of banking service.

\section{Fourth: Analyzing the Results and Testing of the Study Hypotheses Main Hypothesis (Ho)}

There is no statistically significant effect of technical and financial obstacles to the banks' expansion in smart branch applications at Jordanian banks at a significant level $(a \leq 0.05)$.

To test the main hypothesis, the researchers applied the multiple regression test to identify the impact of the technical and financial obstacles on the expansion of banks in the applications of smart branches. The result is shown in Table 5 below.

Table 5. The results of the regression test of the main hypothesis

\begin{tabular}{|c|c|c|c|c|}
\hline Sig. & $\mathrm{F}$ & $\mathrm{R}^{2}$ & \multicolumn{2}{|c|}{$\mathrm{R}$} \\
\hline 0.000 & 50.18 & 0.66 & & 0.81 \\
\hline $\mathrm{T}$ & $\mathrm{T}$ & Standard error & $\mathrm{B}$ & obstacles \\
\hline 0.001 & 3.073 & 0.345 & 0.033 & Technical \\
\hline 0.002 & 1.078 & 0.358 & 1.28 & Financial \\
\hline
\end{tabular}

It is evident from Table 5 that the statistical value (F) reached 50.18 with a significance level of 0.000 and it is less than 0.05 . Therefore, it rejects the null hypothesis and accepts the alternative. This indicates that there is a significant impact of technical and financial obstacles on the expansion of banks in smart branches. Depending on the value of $\mathrm{R}^{2}$, the explanatory and predictive ability of the obstacles explained that the variation in the expansion of banks in the smart branches reached $66 \%$ with other factors remaining constant. Also, it identified most impediments that are affecting the expansion of the smart branches in the banks. The researchers applied the progressive regression analysis as shown in Table 6. 
Table 6. The results of the gradual regression analysis to predict the impact of technical and financial obstacles on the expansion of banks in smart branches

\begin{tabular}{|l|l|l|l|l|l|}
\hline sig. & Beta & $\mathrm{T}$ & $\mathrm{F}$ & $\mathrm{R}^{2}$ & $\begin{array}{l}\text { Order entry } \\
\text { obstacles }\end{array}$ \\
\hline 0.000 & 0.58 & 6.51 & 46.38 & 0.46 & Tech. obstacles \\
\hline 0.000 & 0.61 & 5.69 & 56.73 & 0.73 & Fin. obstacles \\
\hline
\end{tabular}

The results in Table 6 shows that the technical obstacles are in the first rank and explained about $46 \%$ of the variance in the expansion of banks in smart branches, with a value of (f) 46,38 at the level of significance (0.000). The financial obstacles are in the second rank, as was explained with technical obstacles of $73 \%$. Thus, what is explained by the fraud prevention alone is $27 \%$ ( $45 \%-31 \%)$ of the variance on the expansion of banks in smart branches.

The First Sub-hypothesis, Ho-1: There is no statistically significant effect of the technical obstacles on the banks' expansion in the applications of smart branches of Jordanian banks at a significance level $(\mathrm{a} \leq 0.05)$.

Table 7. Results of examining the impact of technical obstacles on the expansion of smart branches by banks

\begin{tabular}{|c|c|c|c|c|}
\hline sig. & $\mathrm{T}$ & Regression coefficient & Independent variable & Dependent variable \\
\hline 0.000 & 6.51 & 46.38 & Tech. obstacles & Smart branches \\
\hline & & $F=5946$ & $\mathrm{R}^{2}=\mathrm{R}=0$ & \\
\hline
\end{tabular}

It is evident from Table 7 that the statistical value (F) reached 59 with a significance level (0.000), which is less than 0.05 . Therefore, it rejects the null hypothesis and accepts the alternative. This indicates that there is an effect of technical obstacles in the expansion of smart branches. Depending on the value of $\mathrm{R}^{2}$, the technical obstacles show a percentage (46\%) of the variance in the expansion of smart branches while other factors remain constant.

The Second Sub-hypothesis, Ho-2: There is no statistically significant effect of the financial obstacles on the expansion of banks in the applications of smart branches at Jordanian banks at a significance level $(a \leq 0.05)$.

Table 8. Results of examining the impact of financial obstacles on the expansion of banks in smart branches

\begin{tabular}{|c|c|c|c|c|}
\hline sig. & $\mathrm{T}$ & $\begin{array}{l}\text { Regression } \\
\text { coefficient }\end{array}$ & Independent variable & Dependent variable \\
\hline 0.000 & 6.51 & 46.38 & Fin. Obstacles & Smart branches \\
\hline \multicolumn{5}{|c}{$\mathrm{F}=6227$} \\
\hline
\end{tabular}

It is evident from Table 8 that the statistical value (F) reached 62 with a significance level (0.000), which is less than 0.05 . Therefore, it rejects the null hypothesis and accepts the alternative. This indicates the existence of an effect of financial obstacles in the expansion of smart branches. Depending on the value of $\mathrm{R}^{2}$, the financial obstacles show a percentage $(27 \%)$ of the 
variance in the expansion of smart branches while other factors remain constant.

\section{Conclusions and Recommendations}

The expansion of smart branches (robots) by banks contributes to reducing operational costs and increasing the completion of tasks in the bank quickly, accurately, and without errors.

There is an effect of the technical obstacles represented by the presence of a specialized staff of workers in the bank to deal with new programs and technologies. Therefore, the study recommends the necessity of the banks 'interest in holding specialized training programs to train them to deal with new technologies.

There is an effect of financial obstacles on the expansion of banks in smart branches (robots) represented by the lack of funds for the infrastructure: hardware, software, databases, networks, communications, the Internet, and protection and safety programs. Therefore, the study recommends the necessity for banks to provide the necessary funds for their investment in infrastructures for smart branches.

\section{References:}

1. Al-Abedallat, Z.A. (2020). Applications of Artificial Intelligence and their Impact on Achieving Competitive Advantage: a study of a Jordanian Bank. The humanities and social sciences series, Jordan, Mutah University, 5(5) 87-122

2. Al-Adaileh, R.M., Al-Mobaideen, H.O., \& Al-Smairat, M.K. (2016). Factors Affecting the Use of Online Banking Services from the Customers' Perspective, Field Study on the Southern Region, Jordan. The Jordan Journal of Business Administration, 12 (3), 531-545. Alahli Bank. http://www.alahlionline.com

3. Al-Fagi, A.I. (2012). Artificial Intelligence and Expert Systems. Dar Al Thaqafa Publishing, and Distribution, Jordan.

4. Al-Hawary, F.A., Bani-hani, J., S., \& Al-Sakarneh, B. (2011). Information Technology Usage Barriers And Their Impact on the Level of Service Quality, An Empirical Study at the Jordanian Banking Sector. Arab Journal of Management, 31 (1), 115-142.

5. Al-Kayat, S.M.A. \& Faidi, J.A.W. (1998). Artificial Intelligence, Concepts, Techniques, methods of programming. $\quad\left(1^{\text {st }}\right.$ edition).Amman: Dar Al-Falah for publication and distribution.

6. Baraokar, S. \& Anand, R. (2018). Techemergence, AI applications in top 4 Indian banks, retrieved from, https: //www.techemergence.com/ai-applications-in-the-top-indian-banks/ 
7. Bibel, W. (2014). Artificial Intelligence in a historical perspective. AI Communications, 27(1), 87-102. DOI: 10.3233/AIC-130576

8. Brush, K. \& Scardina, J. (2019). Chatbot..techtarget in December 2019.https://searchcustomerexperience.techtarget.com/definition/chat bot

9. Castelli, M., Manzoni, L., \& Popovic, A. (2016). An Artificial Intelligence System to Predict Quality of Service in Banking Organizations. Computational Intelligence and Neuroscience, 2016.https://doi.org/10.1155/2016\%2F9139380

10. Central Bank of Jordan. http://www.cbj.gov.jo

11. Dash, S. (2018). Does the Future of Indian Banking Lie In chatbot . Entrepreneur in April 2018. https://www.entrepreneur.com/article/311795

12. Dirican, C. (2015). The Impacts of Robotics, Artificial Intelligence on Business and Economics. Procedia - Social and Behavioral Sciences 195 (2015) 564 - 573. https://doi.org/10.1016/j.sbspro.2015.06.134

13. Doherty, D. \& Curran, K. (2019). Chatbots for online banking services. Web Intelligence, 17(4) 327-342, ISSN: 24056456, http://doi.org/10.3233/WEB-190422

14. Gotthardt, M., Koivulaakso, D., Paksoy, O., Sarmamo, C., Martikainen, M., \& Lehner, O. (2020). Current state and challenges in the implementation of smart robotic process automation in Account and auditing, ACRN Journal of Finance and risk perspectives,9(90102). http://www.acrn-journals.eu/resources/SI08_2019c.pdf

15. H-Farm Industry -AI Team (2017). How artificial intelligence will impact banking and financial services. Retrieved from https://medium.com/h-farm-industry/how-artificaial-intelligencewill-impact-banking-and-financial-services-b2156bc79816 http://abj.org.jo/ar-jo/Home-ar-JO

Https://www.adcb.com/arabic/waystobank/adcbmobile/UBank/overvi ew.asp

16. IBS Intelligence. Role of AI \& RPA in transforming Banking Operation: https://ibsintelligence.com/files/media_temp/HexawareRole_of_AI\&RPA_in_transforming_Banking_Operations_v9.pdf

17. Kanakova, F. \& Prokhorovb, I. (2020). Research and development of software robots for automating business processes of a commercial bank. Procedia Computer Science 169 (2020) 337-341,. https://doi.org/10.1016/j.procs.2020.02.196

18. Kumar, K.S., Tamilselvan, S., Chau, I.B., \& Harish, S. (2018). Artificial Intelligence Powered Banking Chatbots. International Journal of Engineering Sciences Computing, 8 (3), 16134-16137 
https://ijesc.org/upload/4a63d52eda62397d8c051e687773e6d0.Artifi cial\%20Intelligence\%20Powered\%20Banking\%20Chatbot.pdf

19. Mashreqbank . http://www.mashreqbank.com/uae/ar/personal/dogitalbanking/mashraq-online

20. Meyliana, F. \& Surjandy, E. (2019). The Influence of Perceived Risk and Trust in Adoption of FinTech services in Indonesia. Communication \&Information Technology Journal, 13 (1), 31-37.

21. Mohamed, M.A.A. (2017). Obstacles to the technical application of the quality function and its impact on the quality of the services of the banking system. The Arab Journal of Management, 37 (1), 55-76.

22. Nair, K. (2018). Impact of robots on the financial sector. Journal of business and Management (IOSR-JBM), 72-76. http://www.iosrjournals.org/iosrjbm/papers/Conf.ADMIFMS1808-2018/Volume-1/11.\%2072-76.pdf

23. Neill, M. (2018). China bank goes staffless at a branch; robots replace tellers, retrieved from http://www.ejinsight.com/20180417-chinabank-goes-staffless-at-a-branch-robots-replace-tellers/

24. Saleh, F.A.I. (2009). Impact of the Application of Artificial Intelligence and Emotional Intelligence on the Quality of Administrative Decision Making. MA Thesis, Middle East University, Jordan, Amman.

25. Sekaran, U. \& Bougie, R. (2009). Research Methods for Business. $5^{\text {th }}$ edition, John Wiley and Sons Publication.

26. Sharma, P. (2011). Artificial Intelligence. (3th edition, S.K.Katrin\&sons, Publishers of Engineering, P1) and Computer Books.

27. Zikmund,W.G., Babin, B.J., Carr, J.C., \& Griffin, M. (2010). International Research Methods. (8th ed., p306). Canda, Southwestern, Cengage Learning. 